\title{
PENGARUH EFISIENSI MODAL KERJA DAN LIKUIDITAS TERHADAP PROFITABILITAS PADA PERUSAHAAN SUB SEKTOR FARMASI YANG TERDAFTAR DI BURSA EFEK INDONESIA (BEI)
}

\author{
Ellyn Octavianty ${ }^{*}$ dan Defi Jumadil Syahputra ${ }^{* *}$
}

\begin{abstract}
ABSTRAK
Modal kerja dan likuiditas akan berpengaruh pada tingkat profitabilitas perusahaan. Jika modal kerja dan tingkat likuiditas mengalami kenaikan maka profitabilitas perusahaan akan menurun.Penelitian ini ditujukan untuk mengetahui pengaruh modal kerja (working capital turnover, receivable turnover, inventory turnover,) dan likuiditas (current ratio). Hasil penelitian mengungkapkan fakta bahwa $81,1 \%$ profitabilitas (return on asset) dipengaruhi oleh modal kerja (working capital turnover, receivable turnover, inventory turnover) dan likuiditas (current ratio). Sedangkan sebesar 18,9\% dipengaruhi oleh variabel lain yang tidak termasuk dalam model regresi. Perusahaan sektor farmasi memiliki perkembangan modal kerja yang berfluktuasi dan jumlahnya tidak banyak, sedangkan tingkat likuiditas cukup baik. Hal ini berdampak pada rendahnya tingkat profitabilitas yang dihasilkan.
\end{abstract}

Kata Kunci Efisienssi Modal Kerja, Likuiditas, Profitabilitas

\section{Abstract}

Working capital and liquidity will affect the level of corporate profitability. If the working capital and liquidity levels increase the company's profitability will decline. This study aimed to determine the effect of working capital (working capital turnover, receivable turnover, inventory turnover,) and liquidity (current ratio). This research is about the effect of working capital and liquidity to profitability made on the Pharmaceutical Sector Sub listed on the Stock Exchange by using secondary data, purposive sampling method. The analytical method used inferential statistics, namely multiple linear regression analysis using SPSS version 20.Results of the study revealed the fact that $81.1 \%$ of profitability (return on assets) are influenced by working capital (working capital turnover, receivable turnover, inventory turnover) and liquidity (current ratio). While 18.9\% is influenced by other variables not included in the regression model. Company's pharmaceutical sector has fluctuated development of working capital and the amount is not much, while the level of liquidity is quite good. This has resulted in a low level of profitability generated.

Keywords: Efficiency Working Capital, Liquidity, Profitability

\footnotetext{
${ }^{*}$ Dosen Tetap Fakultas Ekonomi Universitas Pakuan

${ }^{* *}$ Mahasiswa Fakultas Ekonomi Universitas Pakuan
} 


\section{Pendahuluan}

Perusahaan farmasi yang berada di Indonesia memiliki permasalahan yang kompleks salah satunya modal kerja. Bagaimana perusahaan tersebut harus mengefisiensikan modal kerja yang ada untuk mendapatkan keuntungan yang optimal adapun perusahaan selalu membutuhkan modal kerja untuk membelanjai kegiatan oprasinya sehari-hari, misalkan untuk pembelian bahan mentah, membayar upah buruh, gaji, pegawai dan lain sebagainya, dimana uang atau dana yang telah dikeluarkan itu diharapkan akan dapat kembali lagi masuk dalam perusahaan dengan jangka waktu yang pendek melalui hasil penjualan produksinya. Manajemen modal kerja adalah kegiatan yang mencangkup semua fungsi manajemen atas aktiva lancar dan kewajiban jangka pendek perusahaan. Sehingga adanya analisis atas modal kerja pada perusahaan, analisis tersebut sangat penting dilakukan untuk mengetahui situasi modal kerja pada saat ini. Kemudian hal itu dihubungkan dengan situasi keuangan yang akan dihadapi pada masa yang akan datang

Modal Kerja adalah keseluruhan dana yang harus dimiliki perusahaan, untuk membiayai kegiatan operasi perusahaan sehari-hari.

Likuiditas yaitu kemampuan suatu perusahaan memenuhi kewajiban jangka pendeknya secara tepat waktu.

Profitabilitas ialah kemampuan manajemen untuk memperoleh laba. Laba terdiri dari laba kotor, laba operasi, dan laba bersih. Untuk memperoleh laba di atas rata-rata, manajemen harus mampu meningkatkan pendapatan (revenue) dan mengurangi semua beban (expenses) atas pendapatan.

Hasil penelitian yang dilakukan padaa perusahaan menunjukan bahwa efisiensi modal kerja tidak berpengaruh terhadap profitabilitas. Hasil ini sesuai dengan teori kasmir (2011). Likuiditas berpengaruh terhadaap profitabilitas. Hasil ini sesuai dengan teori Utari (2012).

Berbagai penelitian mengenai efisiensi modal kerja dan likuiditass terhadap profitabilitas telah dilakukan oleh diantaranya Wawan Setiawan (2013) pada perusahaan indosement tunggal perkasa. Hasil analisis dari penelitian tersebut yaitu bahwa efisiensi modal kerja tidak berpengaruh terhadap profitabilitas, dan likuiditas berpengaruh terhadap profitabilitas. Penelitian yang sama diteliti juga oleh Ririn Soetini (2011) pada perusahaan otomotif. Bahwa efisiensi modal kerja berpengaruh terhadap profitabilitas sedangkan untuk likuiditas tidak berpengaruh terhadap profitabilitas, dari hasil penelitian tersebut terjadi GAP atau hasil penelitian.

Adapun tujuan penelitian yang dilakukan yaitu:

1. Untuk mengetahui perkembangan efesiensi modal kerja pada perusahaan sub sektorfarmasi yang terdaftar di BEIperiode 2009 - 2013.

2. Untuk mengetahui perkembangan likuiditas pada perusahaan sub sektorfarmasi yang terdaftar di BEI periode 2009 - 2013.

3. Untuk mengetahui perkembangan profitabilitas pada perusahaan sub sektorfarmasi yang terdaftar di BEIperiode 2009 - 2013.

4. Untuk mengetahui besarnya pengaruh efesiensi modal kerja dan likuiditas terhadap profitabilitas pada perusahaan sub sektor farmasi yang terdaftar di BEI periode 2009 2013. 


\section{Landasan Teori}

\subsection{Pengertian Modal Kerja}

Pengertian modal kerja menurut Agnes Sawir (2003:129) adalah sebagai berikut: "Modal kerja adalah keseluruhan aktiva lancar yang dimiliki oleh perusahaan, atau dapat pula dimaksudkan sebagai dana yang harus tersedia untuk membiayai kegiatan operasi perusahaan sehari-hari".

Menurut J. Fred Weston dan Eugene F. Brigahm (Kutipan Agnes Sawir, 2003:129) menyatakan bahwa: "Modal kerja adalah investasi perusahaan didalam aktiva jangka pendek seperti kas, sekuritas (surat-surat berharga), piutang dagang dan persediaan".

Menurut Burton A. Kolb (kutipan Agnes Sawir, 2003:129) mengemukakan bahwa: "Working capital is the investment of the firm in short-term or current assets, which includes cash, marketable securities, account receivable, short-term notes receivales, inventories, and in some firms, expense prepayments. (Modal kerja adalah investasi perusahaan dalam aktiva jangka pendek atau lancar, termasuk didalamnya kas, sekuritas, piutang, persediaan, dan dalam beberapa perusahaan, biaya dibayar dimuka)".

Sedangkan menurut Lukas Setia Atmaja (2003:365) mengemukakan bahwa: "Modal kerja atau working capital, sering pula disebut grossworking capitalatau modal kerja kotor. Didefinisikan sebagai item-item pada aktiva lancar, yakni: (cash), sedangkan modal kerja bersih atau net working capital adalah aktiva lancar setelah dikurangi dengan hutang lancar".

Dari pengertian-pengertian modal kerja diatas dapat disimpulkan bahwa modal kerja merupakan sebagai investasi perusahaan atau dana yang tertanam dalam aktiva jangka pendek atau lancar. Seperti kas, piutang dan persediaan yang dibutuhkan perusahaan untuk kebutuhan operasi perusahaan dan selalu berputar dalam jangka pendek.

\subsection{Likuiditas}

Likuiditas merupakan suatu kemampuan perusahaan untuk memenuhi kewajiban jangka pendek. Likuiditas sangat penting bagi suatu perusahaan dikarenakan berkaitan dengan mengubah aktiva menjadi kas.

Likuiditas merupakan suatu indikator mengenai kemampuan perusahaan untuk membayar semua kewajiban finansial jangka pendek pada saat jatuh tempo dengan menggunakan aktiva lancar yang tersedia (Syamsuddin:2011).

Menurut Sartono (2008:116) mengatakan bahwa "Rasio likuiditas menunjukkan kemampuan untuk membayar kewajiban finansial jangka pendek tepat pada waktunya."

Pengertian likuiditas menurut Brigham dan Houston (2010:134), mengatakan bahwa "Aset likuid merupakan asset yang diperdagangkan di pasar aktif sehingga dapat dikonversi dengan cepat menjadi kas pada harga pasar yang berlaku, sedangkan posisi likuiditas suatu perusahaan berkaitan dengan pertanyaan, apakah perusahaan mampu melunasi utangnya ketika utang tersebut jatuh tempo di tahun berikutnya."

Menurut Subramanyam (2012:43) likuiditas, adalah "Untuk mengevaluasi kemampuan memenuhi kewajiban jangka pendek."

Pengertian likuiditas menurut Fred Weston dalam Kasmir (2012:129) adalah "...rasio yang menggambarkan kemampuan perusahaan memenuhi kewajiban (utang) jangka pendek. Artinya apabila perusahaan ditagih, maka akan mampu memenuhi utang (membayar) tersebut terutama utang yang sudah jatuh tempo." 
Dari pengertian likuiditas diatas dapat disimpulkan bahwa likuiditas merupakan suatu indikator mengenai kemampuan perusahaan untuk membayar semua kewajiban finansial jangka pendek pada saat jatuh tempo dengan menggunakan aktiva lancar yang tersedia

\subsection{Pengertian Profitabilitas}

Menurut R. Agus Sartono (2010:122) , yang menyatakan bahwa Profitabilitas adalah kemampuan perusahaan memperoleh laba dalam hubungannya dengan penjualan, total aktiva maupun modal sendiri.

Menurut Kasmir (2011:196), yang menyatakan bahwa Rasio profitabilitas merupakan rasio untuk menilai kemampuan perusahaan dalam mencari keuntungan.

Menurut Susan Irawati (2006:58), yang menyatakan bahwa Rasio keuntungan atau profitability ratios adalah rasio yang digunakan untuk mengukur efisiensi penggunaan aktiva perusahaan atau merupakan kemampuan suatu perusahaan untuk menghasilkan laba selama periode tertentu (biasanya semesteran, triwulanan dan lain-lain) untuk melihat kemampuan perusahaan dalam beroperasi secara efisien.

Berdasarkan pendapat para ahli di atas, dapat ditarik kesimpulan bahwa rasio profitabilitas adalah rasio untuk mengukur tingkat efektifitas pengelolaan (manajemen) perusahaan yang ditunjukkan oleh jumlah keuntungan yang dihasilkan dari penjualan dan investasi. Intinya adalah penggunaan rasio ini menunjukkan efisiensi perusahaan.

\section{Metodologi Penelitian}

Data yang telah dikumpulkan mengenai semua variabel penelitian, kemudian dianalisis dengan menggunakan metode analisis descriptive statistic dan analisis regresi linier berganda untuk mengetahui bagaimana hubungan antar variabel. Pengujian dilakukan dengan alat analisis yaitu regresi linier berganda, uji $\mathrm{F}$ dan uji t. Dalam mengolah data penelitian, penulis menggunakan aplikasi statistic produk and service solution (SPSS) 20.0 for windows.

\section{Hasil dan Pembahasan \\ 1. Analisis Determinasi}

Tabel 13

Hasil Uji Determinasi

Model Summary ${ }^{\mathrm{D}}$

\begin{tabular}{|c|c|c|c|c|c|}
\hline Model & $\mathrm{R}$ & $\mathrm{R}$ Square & $\begin{array}{c}\text { Adjusted R } \\
\text { Square }\end{array}$ & $\begin{array}{c}\text { Std. Error of the } \\
\text { Estimate }\end{array}$ & Durbin-Watson \\
\hline 1 & $.900^{\mathrm{a}}$ & .811 & .735 & 4.2452779 & 2.162 \\
\hline
\end{tabular}

a. Predictors: (Constant), CR, ITO, WCTO, RTO

b. Dependent Variable: ROA

(Sumber: Output SPSS 20, 2014, data diolah penulis)

Berdasarkan pada tabel 13 di atas diperoleh angka $\mathrm{R}^{2}$ ( $\mathrm{R}$ Square) sebesar 0,811 atau $(81,1 \%)$. Hal ini menunjukkan bahwa presentase sumbangan pengaruh variabel independen (working capital turnover, receivable turnover, inventory turnover, current ratio) terhadap variabel dependen (return on assets) sebesar $81,1 \%$. Sedangkan sisanya sebesar $19,9 \%$ dipengaruhi atau dijelaskan oleh variabel lain yang tidak dimasukkan dalam model penelitian ini. 


\section{Uji F (Simultan)}

\begin{tabular}{|c|c|c|c|c|c|c|}
\hline \multicolumn{7}{|c|}{$\begin{array}{c}\text { Tabel } 14 \\
\text { Hasil Uji F (Simultan) }\end{array}$} \\
\hline & Model & Sum of Squares & $\overline{D f}$ & Mean Square & $\bar{F}$ & Sig. \\
\hline \multirow{3}{*}{1} & Regression & 771.476 & 4 & 192.869 & 10.702 & $.001^{\mathrm{D}}$ \\
\hline & Residual & 180.224 & 10 & 18.022 & & \\
\hline & Total & 951.700 & 14 & & & \\
\hline
\end{tabular}

a. Dependent Variable: ROA

b. Predictors: (Constant), CR, RTO, ITO, WCTO

(Sumber: Output SPSS 20, 2014, data diolah penulis)

Berdasarkan tabel 14 diketahui signifikansi $0,01^{\mathrm{b}}$ dan nilai $\mathrm{F}$ test sebesar 10,702. Hal ini tidak sesuai dengan hasil pengujian statistik yang membandingkan antara $\mathrm{F}$ hitung dengan $\mathrm{F}$ tabel, nilai $\mathrm{F}$ tabel $(0,05 ; 4 ; 10)$ adalah 3,48 makahasilnya, $\mathrm{F}$ hitung $>\mathrm{F}$ tabel
$(10,702>3,48)$ sehingga dapat disimpulkan bahwa variabel independen receivable turnover, inventory turnover, working capital turnover, current ratio secara simultan mempengaruhi variabel dependen ROA

\section{Uji t (Parsial)}

Tabel 15

\section{Hasil Uji t (Parsial)}

\begin{tabular}{|c|c|c|c|c|c|c|}
\hline \multicolumn{7}{|c|}{ Coefficients $^{a}$} \\
\hline \multirow{2}{*}{\multicolumn{2}{|c|}{ Model }} & \multicolumn{2}{|c|}{ Unstandardized Coefficients } & \multirow{2}{*}{$\begin{array}{c}\text { Standardized } \\
\text { Coefficients } \\
\text { Beta }\end{array}$} & \multirow[t]{2}{*}{$\mathrm{t}$} & \multirow[t]{2}{*}{ Sig. } \\
\hline & & $\mathrm{B}$ & Std. Error & & & \\
\hline \multirow{5}{*}{1} & (Constant) & -11.961 & 17.450 & & -.685 & .509 \\
\hline & WCTO & 2.628 & 4.859 & .096 & .541 & .600 \\
\hline & RTO & .158 & .163 & .137 & .967 & .356 \\
\hline & ITO & .035 & .858 & .006 & .041 & .968 \\
\hline & CR & 5.775 & 1.087 & .955 & 5.314 & .000 \\
\hline
\end{tabular}

a. Dependent Variable: $\mathrm{ROA}$

(Sumber: Output SPSS 20, 2014, data diolah penulis)

1. Nilai signifikansi working capital turnover sebesar 0,600 lebih besar dari 0,05 (sig. $\mathrm{t}>0,05$ ) telah sesuai dengan hasil pengujian statistik yang membandingkan antara t hitung dengan $t$ tabel. Hal ini ditunjukkan dengan $\mathrm{t}$ hitung $<\mathrm{t}$ tabel $(0,541<1,812)$.

2. Nilai signifikansi receivable turnover sebesar 0,356 lebih besar dari 0,05 (sig. $t>0,05$ ). Hal ini sesuai dengan hasil pengujian statistik yang membandingkan antara t hitung dengan $t$ tabel, nilai t tabel $(0,05 ; 10)$ adalah 1,81246 maka hasilnya, $\mathrm{t}$ hitung $>\mathrm{t}$ tabel $(0,967<1,812)$.

3. Nilai signifikansi inventory turnover sebesar 0,968 lebih besar dari 0,05 (sig. $\mathrm{t}>0,05$ ) telah sesuai dengan hasil pengujian statistik yang membandingkan antara $\mathrm{t}$ 
hitung dengan $\mathrm{t}$ tabel. Hal ini ditunjukkan dengan $\mathrm{t}$ hitung $<\mathrm{t}$ tabel $(0,410<1,812)$.

4. Nilai signifikansi current ratio sebesar 0,000 kurang dari 0,05 (sig. $\mathrm{t}>0,05$ ) telah sesuai dengan hasil pengujian statistik yang membandingkan antara $\mathrm{t}$ hitung dengan $\mathrm{t}$ tabel. Hal ini ditunjukkan dengan $\mathrm{t}$ hitung $<\mathrm{t}$ tabel $(5.314$ $>1,812$ ).

Empat variabel independen tersebut yang dimasukkan ke dalam model regresi ini working capital turnover, receivable turnover, inventory turnover, current ratio memiliki pengaruh terhadap return on assets.

\section{Analisis Regresi Berganda}

Berdasarkan output spss tabel 16 diperoleh persamaan regresi sebagai berikut:

$\mathrm{ROA}=$

$$
11,961+2,628+0,158+0,035+5,775
$$

Dari hasil persamaan regresi berganda tersebut dijelaskan bahwa:

1. $\quad \beta 0=$ konstanta sebesar $-11,961$ artinya apabila semua variabel independen (WCTO, RTO, ITO, dan CR) dianggap konstan (bernilai 0), maka return on assets akan mengalami peningkatan sebesar -11.961.

2. Working Capital Turnover (WCTO) sebesar 2,628 artinya apabila working capital turnover perusahaan naik sebesar 1 satuan sedangkan variabel lainnya dianggap konstan maka return on assets akan mengalami penurunan sebesar 2,628 satuan.

3. Receivable Turnover (RTO) sebesar 0,158 artinya apabila receivable turnover perusahaan naik sebesar 1 satuan sedangkan variabel lainnya dianggap konstan maka return on assets akan mengalami penurunan sebesar 0,158 satuan.

4. Inventory Turnover (ITO) sebesar 0,035 artinya apabila inventory turnover perusahaan naik sebesar 1 satuan sedangkan variabel lainnya dianggap konstan maka return on assets akan mengalami peningkatan sebesar 0,035 satuan.

5. Current Ratio (CR) sebesar 5,775 artinya apabila current ratio perusahaan turun sebesar 1 satuan sedangkan variabel lainnya dianggap konstan maka return on assets akan mengalami penurunan sebesar 5,775 satuan.

Berdasarkan hasil penelitian ini, maka di bawah ini penulis menginterpretasikan hasil penelitian yang diperkuat dengan hasil penelitian-penelitian sebelumnya. Working Capital Turnover tidak berpengaruh terhadap return on assets. Return On Assets mengukur kemampuan perusahaan menghasilkan laba bersih berdasarkan tingkat aset tertentu. Working Capital Turnover bertujuan untuk mengukur seberapa banyak modal kerja berpitar dalam suatu periode. Jadi, apabila working capital turnover mengalami kenaikan maka tidak akan berpengaruh pada return on assets. selain itu, hasil penelitian ini tidak konsisten dengan penelitian yang dilakukan oleh Wawan Setiawan (2013).

Berdasarkan hasil penelitian ini, receivable turnover tidak berpengaruh terhadap return on assets. Return On Assets mengukur kemampuan perusahaan menghasilkan laba bersih berdasarkan tingkat aset tertentu. Receivable turnover bertujuan untuk mengukur berapa kali dana yang tertanam dalam piutang berputar dalam satu periode, jadi apabila receivable turnover mengalami kenaikan maka return on assets juga mengalami 
kenaikan. Penelitian ini sesuai dengan penelitian yang dilakukan oleh Ririn Setiorini (2009).

Berdasarkan hasil penelitian ini, inventory turnover tidak berpengaruh terhadap return on asset. Return on assets mengukur kemampuan perusahaan menghasilkan laba bersih berdasarkan tingkat aset tertentu. inventory turnover bertujuan untuk mengukur berapa kali dana yang ditanam dalam persediaan berputar dalam suatu periode. Jadi, apabila inventory turnover mengalami kenaikan maka tidak akan berpengaruh pada return on assets. Selain itu, hasil penelitian ini tidak konsisten dengan penelitian yang dilakukan oleh Ririn Setiorini (2009) yang menyatakan bahwa secara simultan dan parsial terdapat pengaruh positif antara variabel modal kerja (inventory turnover ratio) terhadap profitabilitas.

Berdasarkan hasil penelitian ini, current ratio berpengaruh terhadap return on assets. Return on assets mengukur kemampuan perusahaan menghasilkan laba bersih berdasarkan tingkat aset tertentu. Current ratio bertujuan untuk mengukur kemampuan perusahaan dalam memenuhi kewajibankewajiban finansialnya yang harus segera dipenuhi. Jadi, apabila current ratio mengalami penurunan maka akan berpengaruh pada return on assets. Selain itu, hasil penelitian ini konsisten dengan penelitian yang dilakukan oleh Wawan Setiawan (2013) yang menyatakan bahwa terdapat pengaruh positif antara current ratio terhadap profitabilitas.

\section{Penutup}

\subsection{Simpulan}

1. Berdasarkan hasil penelitian ini perusahaan sub sektor farmasi pada periode 2009-2013 memiliki perkembangan modal kerja seperti. a. Rata-rata perkembangan nilai signifikan working capital turnover perusahaan telah sesuai dengan hasil pengujian statistik yang membandingkan antara $t$ hitung dengan $t$ tabel. Sehingga kesimpulanya adalah modal kerja (working capital turnover) tidak berpengaruh tehadap profitabilitas (return on assets) dan hipotesis ditolak. (Working Capital Trunover) bertujuan untk mengukur seberapa banyak modal kerja berputar dalam satu periode. Jadi, apa bila (Working Capital Trunover) mengalami kenaikan maka tidak akan berpengaruh pada (return on assets). Hasil penelitian ini tidak konsisten dengan penelitian yang dilakukan oleh Wawan Setiawan (2013).

b. Rata-rata perkembangan nilai signifikan (receivable turnover) perusahaan. Hal ini sesuai dengan hasil pengujian statistik yang membandingkan antara $\mathrm{t}$ hitung dengan $t$ tabel. Sehingga dapat disimpulkan bahwa modal kerja (receivable turnover) tidak berpengaruh terhapap profitabilitas (return on assets) dan hipotesis ditolak. (Receivable Turnover) bertujuan untuk mengukur berapa kali dana yang tertanam dalam piutang berputar dalam satu periode. Jadi apabila (receivable turnover) mengalami kenaikan maka (return on assets) juga mengalami 
kenaikan. Penelitian ini sesuai dengan penelitian yang dilakukan oleh Ririn Setiorini (2009).

c. Rata-rata perkembangan nilai signifikan (inventory turnover) perusahaan. Hal ini telah sesuai dengan hasil pengujian statistik yang membandingkan antara $t$ hitung dengan $\mathrm{t}$ tabel. Jadi disimpulkan bahwa modal kerja (inventory turnover) tidak berpengaruh terhadap profitabilitas (return on assets) dan hipotesis ditolak. (Inventory Turnover) bertujuan untuk mengukur berapa kali dana yang ditanam dalam persediaan berputar dalam suatu periode. Jadi apabila (inventory turnover) mengalami kenaikan maka tidak akan berpengaruh pada (return on assets). Hasil penelitian ini sesuai dengan penelitian yang dilakukan oleh Ririn Setiorini (2009).

2. Berdasarkan hasil penelitian ini perusahaan sub sektor farmasi pada periode 2009-2013 memiliki perkembangan likuiditas seperti rata-rata perkembangan nilai signifikan (current ratio) perusahaan. Hal ini telah sesuai dengan hasil pengujian statistik yang membandingkan antara $t$ hitung dengan $\mathrm{t}$ tabel. Sehingga kesimpulanya adalah likuiditas (current ratio) berpengaruh positif terhadap profitabilitas (return on assets) dan hipotesis diterima. (Current Ratio) bertujuan untuk mengukur kemampuan perusahaan dalam memenuhi kewajibankewajiban finansialnya yang harus segera dibayar tepat waktu. Jadi apabila (current ratio) mengalami penurunan maka akan berpengaruh pada (return on assets). Hasil penelitian ini konsisten dengan penelitian yang dilakukan oleh Wawan Setiawan (2013).

3. Berdasarkan hasil penelitian ini perusahaan sub sektor farmasi pada periode 2009-2013 memiliki perkembangan profitabilitas (return on assets) melalui uji koefisien determinasi diketahui sebesar $81,1 \%$ (working capital turnover, receivable turnover, inventory turnover, current ratio) sedangkan sisanya sebesar $18,9 \%$ dipengaruhi oleh variabel lain yang tidak termasuk dalam model regresi. (Return On Assets) Bertujuan mengukur kemampuan suatu perusahaan untuk menghasilkan laba dalam suatu periode tertentu dengan asset yang dimiliki oleh perusahaan tersebut.

4. Berdasarkan hasil penelitian ini perusahaan sub sektor farmasi pada periode 2009-2013. Hasil penelitian dengan pengujian statistik menunjukkan secara simultan (bersama-sama) bahwa modal kerja dan likuiditas berpengaruh terhadap profitabilitas. Sementara secara parsial (individu) hanya current ratio yang berpengaruh terhadap profitabilitas (return on assets). Hal ini menunjukkan bahwa apabila current ratio mengalami kenaikan maka return on assets juga mengalami hal yang sama.

\subsection{Saran}

Penelitian ini memberikan kontribusi dalam pengembangan ilmu pengetahuan di bidang ekonomi akuntansi pada umumnya dan khususnya mengenai akuntansi keuangan, bahwa 
sebesar $81,1 \%$ profitabilitas (return on assets) dipengaruhi oleh modal kerja (working capital turnover, receivable turnover, inventory turnover,) dan likuiditas (current ratio). Sedangkan sisanya sebesar 18,9\% dipengaruhi oleh variabel lain yang tidak termasuk dalam model regresi.

Penelitian ini hanya terbatas pada variabel tertentu, periode terbatas, dan jumlah unit analisis terbatas. Disarankan untuk penelitian selanjutnya dapat mengurangi keterbatasan ini, yaitu sebaiknya penelitian selanjutnya menggunakan variabel yang lebih bervariasi seperti Weight Average Cost of Capital, Cash Ratio, Cash Turnover, Gross Profit Margin, Net Profit Margin, dan Return On Equity. Periode penelitian sebaiknya diatas 5 tahun dengan menggunakan sampel yang lebih besar pada perusahaan selain sektor farmasi, seperti sektor aneka industri, keuangan, pertanian, dan pertambangan.

Hasil penelitian ini dapat digunakan oleh berbagai pihak, antara lain:

1. Bagi investor dan kreditur

Sebaiknya investor dan kreditur memperhatikan tingkat likuiditas dan profitabilitas. Tingkat likuiditas yang terlalu tinggi menunjukkan bahwa kas perusahaan tidak digunakan secara optimal sebagai modal kerja operasional dan tingkat profitabilitas (return on assets) yang rendah menunjukkan perusahaan belum mampu menghasilkan laba dengan modal kerja sendiri yang dimiliki. Perusahaan cenderung menggunakan dana pinjaman dari luar perusahaan. Selain itu, investor dan kreditur harus mengetahui dan memahami siklus bisnis perusahaan sub sektor farmasi.

2. Bagi Perusahaan

Manajemen bertanggung jawab dalam menghasilkan keuntungan (profit) bagi perusahaan. Manajemen harus berupaya meningkatkan penggunaan modal kerja yang dimiliki untuk menjalankan operasionalnya, menyimpan dana di tangan (cash on hand) dalam jumlah yang normal sesuai kebutuhan untuk membayar kewajiban jangka pendek, serta menjaga keseimbangan proporsi antara modal kerja yang dimiliki dengan dana pinjaman yang digunakan sebagai modal kerja operasional.

\section{DAFTAR PUSTAKA}

Agus Sartono. 2007. Sistem Pengendalian manajemen, Binarupa Aksara, Jakrta.

Anthony, Robert N. dan Govindarajan, Vijay. 2008. Sistem Pengendalian Manajemen, Salemba Empat, Jakarta.

Brigham, Eugene F, dan Houston, Joel F. 2006. Dasar-dasar Manajemen Keuangan (Fundamental of Financial Management). Jilid 1 Edisi 10, Penerbit Salemba Empat, Jakarta.

Djawanto. 2008. Penerapan manajemen keuangan. Salemba Empat, Jakarta.

Dwi Utari dkk. 2014. Manajemen Keuangan. Edisi Revisi, Mitra wacana Media, Jakarta.

Esra, Apriweni 2009. Analisa Kinerja Keuangan dan Pembelanjaan Perusahaan, PT. Gramedia Pustaka Umum, Jakarta

Haryati, Risma 2011. Pengaruh Modal Kerja dan Likuiditas terhadap Profitabilitas pada PT.UNILEVER INDONRESIA Tbk. Skripsi Program Studi Manajemen Universitas Komputer Indonesia, Bandung.

Husman, Sad. 2007. Manajemen Keuangan: Teori dan Penetapan (Keputusan Jangka Pendek). BPFE. Yogyakarta.

Home, james C Van dan John M. Wachowich, JR. 2009. Prinsip- 
prinsip manajemen Keuangan.

Salemba Empat, Jakarta.

Irham Fahmi. 2012. Analisis Laporan Keuangan. Alfabeta Bandung, Bandung.

Jumingan. 2008. Analisis Laporan Keuangan, Bumi Aksara, Surakarta.

Kasmir. 2010. Analisis laporan Keuangan. Rajawali Pers, Jakarta.

Lokollo, Antonius 2013. Pengaruh Manajemen Modal Kerja dam Rasio Keuangan terhadap Profitabilitas pada Perusahaan manufaktur yang Terdaftar di Bursa Efek Indonesia Tahun 2011. Skripsi Fakultas Ekonomika dan Bisnis/Akuntansi. Universitas Diponogoro, Semarang.

Mamduh M. Hanafi, Abdul halim. 2009. Analisis Laporan Keuangan. UPP STIM YKPN, Yogyakarta.

Martono dan Agus Harjito. 2012. "Manajemen Keuangan". Ekonosia. Yogyakarta.

Munawir, S. 2009. Analisis Laporan Keuangan. Liberty Yogyakarta, Yogyakarta.

Prihadi, Toto. 2010. Analisis Laporan Keuangan Lanjutan. Ppm manajemen, Jakarta,

Riyanto, Bambang. 2008. Dasar-dasar Pembelanjaan Perusahaan. BPFE, Yogyakarta.
Santoso, Agus. 2010. Dasar-dasar analisis Laporan Keuangan. Rhineka Cipta. Yogyakarta

Sartono. 2009. Manajemen Keuangan Satu Edisi Kelima. PT Prehallindo. Jakarta.

Saworno, Jonathan. 2010. Analisis Data Penelitian (Menggunakan Program SPSS). PT Gramedia Pustaka Umum, Jakarta.

Sawir, Agnes. 2008. Analisis Kinerja Keuangan dan Perancanaan Keuangan Perusahaan. PT Gramedia Pustaka Utama. Jakarta.

Sjahrial, Djahotman, 20013. Pengantar Manajemen Keuangan. Mitra Wacana Media, Jakarta.

Soetini, Ririn. 2009. Analisis Pengaruh modal Kerja terhadap Profitabilas pada Perusahaan Maufaktur yang Terdaftar di Bursa Efek Indonesia. Skripsi Program Studi Manajemen Fakultas Ekonomi dan Ilmu Sosial, UIN Syarif Hidatatullah, Jakarta.

Sugiyono. 2013. Metodologi Penelitian Kuantitatif Kualitatif dan $R \& D$. Alfabeta, Bandung.

Sutrisno. 2009. Manajemen Keuangan: Teori , konsep \& Aplikasi. Ekonisia Yogyakarta.

Syamsuddin, Lukman. 2007. Manajemen Keuangan Perusahan. Raja Grafindo Persada, Jakarta. 